\title{
Application of "CERDIK" Behavior Model in Schools as an Effort to Improve Diabetes Mellitus Prevention Behavior
}

\author{
Penerapan Model Perilaku "CERDIK" di Sekolah Sebagai Upaya Peningkatan Perilaku \\ Pencegahan Diabetes Melitus
}

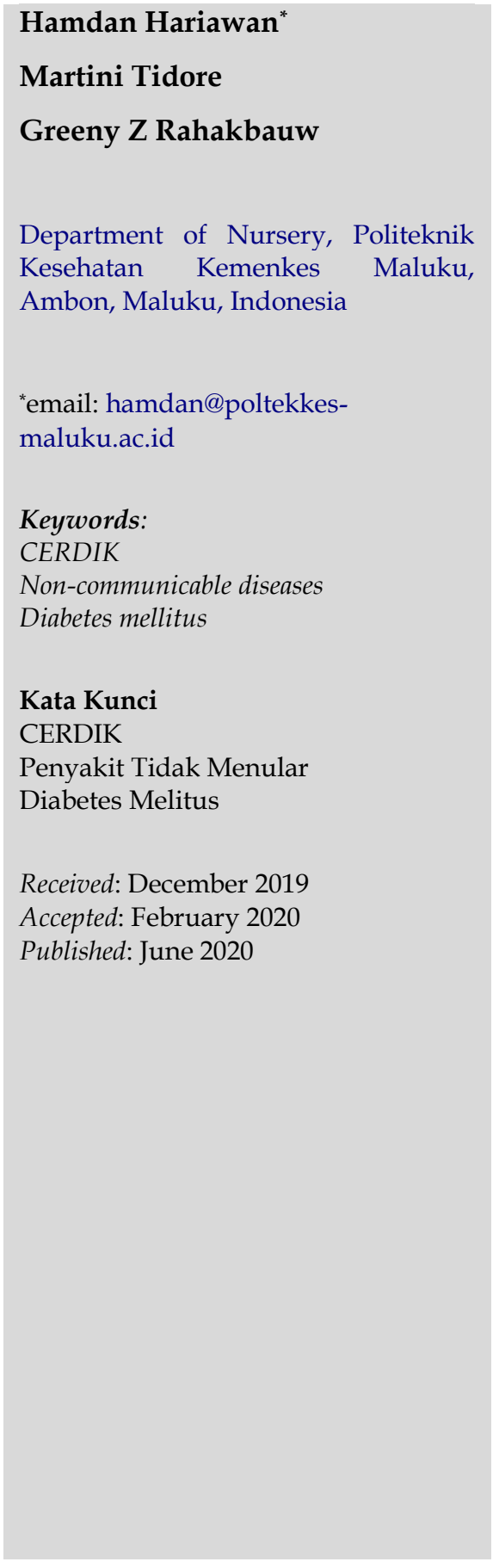

\begin{abstract}
The prevalence of non-communicable diseases such as diabetes mellitus continues to increase every year. Teenagers today cannot be separated from unhealthy lifestyles such as smoking, eating fast food, online gaming, and lack of physical activity. The data obtained that 60 to 80 smoker students in Ambon State Aliyah Madrasah which is the work area of the Air Besar Health Center. In the Air Besar Health Center in the past year, there were 207 diabetes mellitus sufferers. The expected outcome and outcome of this Community Service is increasing students' knowledge and skills towards diabetes mellitus with CERDIK behavior in schools. The service method is carried out through education and training through demonstrations. Demonstrations were given related to CERDIK behavior such as how to prevent smoking, how to manage stress, and how to read food packaging labels to reduce sugar consumption. So the results and outcomes obtained are increased knowledge and skills of students as participants of CERDIK behavior in schools. The series of community service activities can be carried out properly according to the plan. And it is expected that the person in charge of the UKS will provide other students with the CERDIK module in the school that has been given and the involvement of the Health Center is running the Non-Communicable Disease program in schools as a continuation of community service.
\end{abstract}

\begin{abstract}
Abstrak
Prevalensi penyakit tidak menular seperti diabetes melitus terus meningkat setiap tahunnya. Remaja saat ini tidak lepas dari gaya hidup yang tidak sehat seperti merokok, mengonsumsi makanan siap saji, gaming online dan aktivitas fisik yang kurang. Didapatkan data bahwa 60 hingga 80 siswa perokok di Madrasah Aliyah Negeri Ambon yang merupakan wilayah kerja Puskesmas Air Besar. Di Puskesmas Air Besar dalam satu tahun terakhir ini didapatkan sejumlah 207 penderita diabetes melitus. Luaran dan hasil yang diharapkan dari Pengabdian kepada Masyarakat ini adalah meningkatnya pengetahuan dan keterampilan siswa terhadap diabetes melitus dengan perilaku CERDIK di sekolah. Metode pengabdian dilakukan dengan Pendidikan dan pelatihan melalui demonstrasi. Demonstrasi yang diberikan terkait dengan perilaku CERDIK seperti cara pencegahan merokok, cara mengelola stress dan cara membaca label makanan kemasan untuk mengurangi konsumsi gula. Sehingga hasil dan luaran yang didapatkan adalah meningkatnya pengetahuan dan keterampilan siswa sebagai peserta terhadap perilaku CERDIK di sekolah. Rangkaian kegiatan pengabdian kepada masyarakat dapat dilaksanakan dengan baik sesuai dengan rencana. Dan diharapkan penanggungjawab UKS membekali siswa lainnya dengan modul CERDIK di sekolah yang telah diberikan serta keterlibatan puskesmas dalam menjalankan program Penyakit Tidak Menular di sekolah sebagai keberlanjutan dari pengabdian kepada masyarakat ini.
\end{abstract}




\section{INTRODUCTION}

Diabetes mellitus (DM) is one of the most dramatic diseases in society and has been named as one of four non-communicable diseases that are prioritized to become a serious follow-up target by leaders in the world. The number of cases and the prevalence of DM continue to show an increasing trend in recent decades (Al-Lawati, 2017). The most impacting effect caused by this type of disease is exacerbating the death of people up to 5-10 years shorter. The life expectancy of patients with type 2 diabetes, with severe mental disorders, such as schizophrenia, has been shown to reach $20 \%$ shorter than ordinary people (Annamalai \& Tek, 2015). The results of Riset Kesehatan Dasar (Basic Health Research) or RISKESDAS in 2018 show that the prevalence of noncommunicable diseases has increased since 2013. Regarding blood sugar testing, DM increased from 6.9\% to $8.5 \%$ from 2013 to 2018 . The digestive pattern is not balanced, with high levels of sugar, salt, and fat, are also considered factors that contribute to the increasing trend of the phenomenon of obesity in adults as a risk factor for non-communicable diseases. Increased obesity growth can be referred to the RISKESDAS results, with a percentage of $10.5 \%$ (2007), $14.8 \%$ (2013), and $21.8 \%$ (2018). In the long run, this kind of risk can accumulatively trigger the presence of noncommunicable diseases, such as hypertension, DM, and stroke, which will grow significantly higher for everyone in all socioeconomic backgrounds. So, there will be potential complications (Riset Kesehatan Dasar, 2018).

Ambon City has shown a prevalence of DM 1.9\% of all 2.1\% occurrences in Maluku Province based on National parameters. The youngest patients from Diabetes Mellitus average age 15 years. The results of interviews with Rijali Community Health Service officers in Ambon City showed that there were 207 DM incidents. Madrasah Aliyah Negeri (State Islamic MiddleSchool) or
MAN Ambon is one of the educational institutions, which is part of the Rijali Community Health Services operations area. Students at school have the potential to suffer from DM. Besides the background of parents, the potential grows because of their lifestyle.

In addition, CERDIK is designed as one of the government programs to increase the effectiveness of preventive measures from potential non-communicable diseases; one of them is DM (Hariawan \& Pefbrianti, 2020). CERDIK consists of a series of programs to examine health together by giving participants knowledge about diabetes mellitus, developing smokefree behavior or stopping smoking, spreading awareness about the importance of physical activity, reducing the level of consumption of sugar, salt, and fat, and increasing the level of consumption of vegetables and fruit and make good rest and good stress management (Ministry of Health of the Republic of Indonesia, 2016). Some literature discusses activities related to the CERDIK program to prevent diabetes mellitus, such as maintaining a diet, not smoking, increasing the intensity of physical activity, and managing stress properly. All of the above activities are intended to reduce the incidence of DM (Susanti \& Bistara, 2018; Ario, 2014). In addition, CERDIK has an extraordinary advantage in building people's habits to always have a healthy lifestyle as a preventative measure from non-communicable diseases such as DM (Ambarwati \& Prihastuti, 2019; Suryani et al., 2018).

\section{METHOD}

Methods for conducting community services include designing material in the form of 'CERDIK Modules in Schools', evaluating background knowledge and skills of participants about DM and CERDIK behavior in schools through pre-tests, educating students about DM and CERDIK in Schools with reference to basic information 
about DM, the risk of smoking on the incidence of DM, the benefits and types of physical activities that are feasible at school as well as the effects of stress, showing how to apply CERDIK, as well as a final evaluation of participants' knowledge and skills about DM and CERDIK behavior in schools with a post-test..

\section{RESULTS AND DISCUSSION}

The results of this community service program are in the form of improving the behavior of participants after being educated and showing CERDIK behavior in schools. The increase refers to increasing knowledge about DM and awareness of CERDIK behavior. Increased awareness of CERDIK behavior is manifested through several actualizations, such as stopping smoking, reducing sugar consumption, doing physical activity, and maintaining stress management. Figure 1 show that the increased knowledge shown by participants in DM highlights aspects of the definition, risk factors, and symptoms of diabetes mellitus. In general, the results of this community service aim to increase public awareness of the occurrence of DM. Increased knowledge about DM is the result of the Health Education program, which is also part of this community service program. The education program is designed by showing interesting material with proportional delivery of materials and adjusted to the age of the participant, which is also an influencing factor for increasing participant knowledge (Mando et al., 2018).

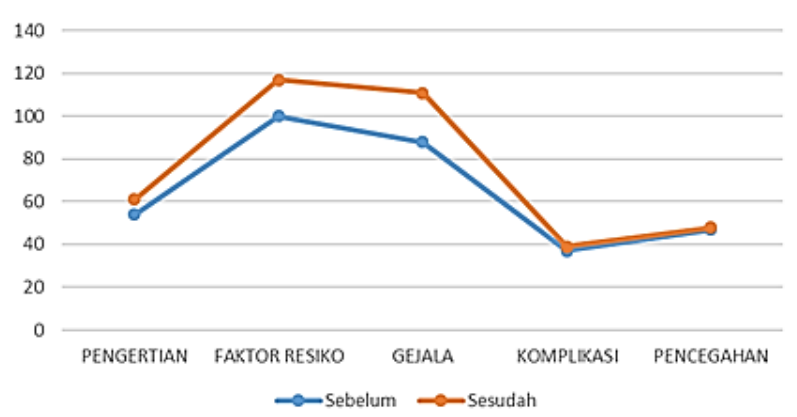

Figure 1. Participants knowledge of DM
In addition, the material is also delivered in the simplest language, which contains a collection of enchanting posters taken from the P2PTM Ministry of Health of the Republic of Indonesia. Increased knowledge is also influenced by the age factor involving the participants. Because they are aged between 10 and 19 years, it is generally believed that age is the stage where people can satisfactorily achieve the maximum results from what they learn (Asfar \& Asnaniar, 2018; Gamage \& Jayawardana, 2017). Figure 2 shows the increase in knowledge exhibited by participants about CERDIK's behavior after the community engagement session. In line with those related to diabetes mellitus, this clear increase is a matter of attractive appearance and interactive delivery of material based on participant age. The material is in the form of interesting posters taken from P2PTM Ministry of Health of the Republic of Indonesia. These results indicate that there has been a transformation of knowledge as expected before this program. Knowledge improvement occurs because of information provided to people through the Health Education program, where the learning process also occurs (Mando et al., 2018).

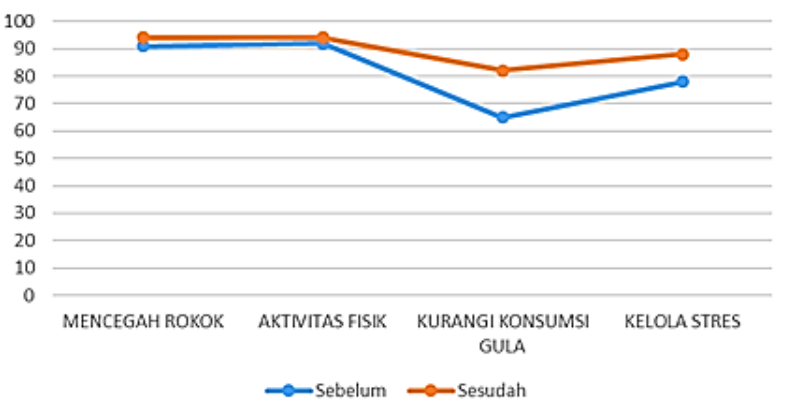

Figure 2. Participants knowledge of CERDIK behavior

Figure 3 illustrates that the improvement in CERDIK behavior in schools is significant after the community service program ends. Improved behavior can be seen from increased physical activity and stress management activities. On average, physical activity increases due to 
physical activity outside the physical education subjects taught at school, while stress management is often done through recitation of the Qur'an. In addition, the improvement in behavior and skills after the community engagement session, which is manifested in the form of Health Education, can be influenced by the domain of good character development, especially with a good level of knowledge (Wang et al., 2018).

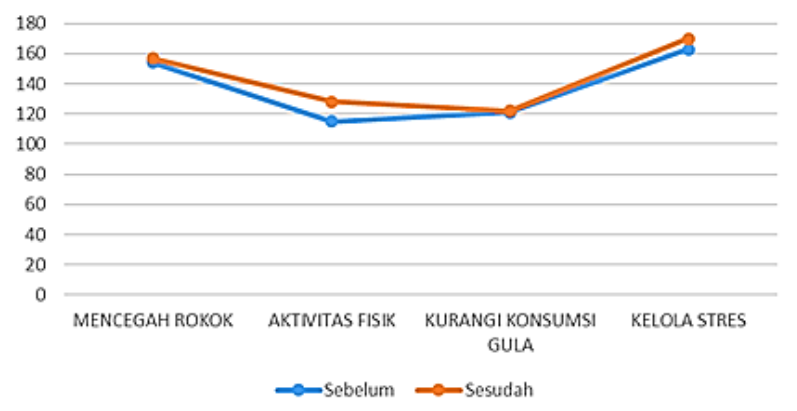

Figure 3. Participants CERDIK behavior in school

SMART Behavior in Schools consists of several preventive measures from non-communicable diseases, such as diabetes mellitus, such as stopping smoking, reducing sugar consumption, and managing stress. In general, the results of this community engagement session showed a trend of increasing knowledge and behavior of CERDIK in Schools. Such behavior is demonstrated through skills and actions that satisfy CERDIK feelings, such as being able to define a Body Mass Index, read sugar levels on food labels, and manage stress by relaxing deep breaths.

In addition, the results of this program are also in the form of cooperation between the community engagement program council, the Health Polytechnic of the Ministry of Health of Maluku, and the Air Besar Health Center, which is responsible for the area where the community engagement session is being held. This was demonstrated by the presence of the management board of the Air Besar Health Center in MAN Ambon, as a location determined from the community involvement session to assist in the rapid examination of blood sugar, cholesterol and gout for school teachers. In addition, the Air Besar Health Center management board supports the CERDIK program in Schools, which will be a routine agenda for public health services in the Air Besar Health Center non-communicable disease program.

\section{CONCLUSION}

CERDIK behavior in schools for MAN Ambon students increases, in terms of knowledge and skills of CERDIK behavior, after the program ends. To maintain the sustainability of this program with the community, therefore, those responsible for UKS need to educate students using the CERDIK module in Schools. In addition, it is recommended that the Health Office be involved in running non-communicable disease program in schools.

\section{ACKNOWLEDGMENT}

Thank you to the Director of the Health Ministry of the Maluku Health Polytechnic, the Head of the Research Center of the Health Ministry of the Maluku Health Polytechnic, the Head of the Air Besar Health Center, the Head of the Ambon State Aliyah Madrasah, and all the stakeholders who have contributed to our community involvement.

\section{REFERENCES}

Al-Lawati, J.A. 2017. Diabetes Mellitus: A Local and Global Public Health Emergency! Oman Medical Journal. 32(3):177-179. https://dx.doi.org/10.5001/omj.2017.34

Ambarwati, E.R., Prihastuti, P. 2019. Gerakan Masyarakat Hidup Sehat (GERMAS) Mencuci Tangan Menggunakan Sabun Dan Air Mengalir Sebagai Upaya Untuk Menerapkan Perilaku Hidup Bersih DanSehat (PHBS) Sejak Dini. Celebes Abdimas: Jurnal Pengabdian Kepada Masyarakat. 1(1):45-52. 
Annamalai, A., Tek, C. 2015. An Overview of Diabetes Management in Schizophrenia Patients: Office Based Strategies for Primary Care Practitioners and Endocrinologists. International Journal of Endocrinology.

2015:969182. https://doi.org/10.1155/2015/969182

Ario, M.D. 2014. Effect of Nicotine in Cigarette for Type 2 Diabetes Mellitus. Majority (Medical Journal of Lampung University). 3(7):75-80.

Asfar, A., Asnaniar, W.O.S. 2018. Pengaruh Penyuluhan Kesehatan Terhadap Tingkat Pengetahuan Dan Sikap Tentang Penyakit HIV/AIDS Di Smp Baznas Provinsi Sulawesi Selatan. Journal of Islamic Nursing. 3(1):26-31. https://doi.org/10.24252/join.v3i1.5471

Gamage, A.U., Jayawardana, P.L. 2017. Knowledge of Non-Communicable Diseases and Practices Related to Healthy Lifestyles Among Adolescents, in State Schools of a Selected Educational Division in Sri Lanka. BMC Public Health. 18(1):64. https://doi.org/10.1186/s12889-017-4622-z

Hariawan, H., Pefbrianti, D. 2020. Cerdik Meningkatkan Pengendalian Penyakit Tidak Menular Di Indonesia: Systematic Review. 2-trik: TunasTunas Riset Kesehatan. 10(1):16-20. http://dx.doi.org/10.33846/2trik10104

Mando, N.J., Widodo, D., Sutriningsih, A. 2018. Hubungan Dukungan Keluarga Dengan Kepatuhan Minum Obat Pada Pasien TB di Puskesmas Janti Kota Malang. Nursing News: Jurnal Ilmiah Mahasiswa Keperawatan. 3(3):550556.

Ministry of Health of the Republic of Indonesia. 2016. Germas Wujudkan Indonesia Sehat. Kementerian Kesehatan Republik Indonesia

Riset Kesehatan Dasar. 2018. Hasil Utama Riskesdas 2018. Jakarta: Health Research and Development Agency Ministry of Health Republic of Indonesia.

Suryani, D., Nurdjanah, E.P., Yogatama, Jumadil, M. 2018. Membudayakan Hidup Sehat Melalui Gerakan Masyarakat Hidup Sehat (GERMAS) di Dusun Mendang III, Jambu dan Jrakah Kecamatan, Tanjungsari, Gunungkidul. Jurnal Pemberdayaan: Publikasi Hasil Pengabdian Kepada Masyarakat. 2(1):65-74. https:/ /doi.org/10.12928/jp.v2i1.486
Susanti, S., Bistara, D.N. 2018. Hubungan Pola Makan Dengan Kadar Gula Darah Pada Penderita Diabetes Mellitus. Jurnal Kesehatan Vokasional. 3(1):29-34. https://doi.org/10.22146/jkesvo.34080

Wang, M., Han, X., Fang, H., Xu, C., Lin, X., Xia, S., Yu, W., He, J., Jiang, S., Tao, H. 2018. Impact of Health Education on Knowledge and Behaviors Toward Infectious Diseases Among Students in Gansu Province, China. BioMed Research International. 2018:6397340. https://doi.org/10.1155/2018/6397340 